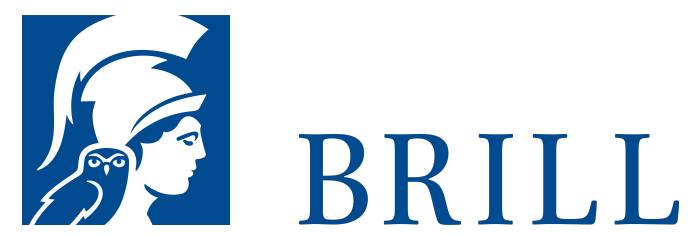

\title{
International Exchange in the Early Modern Book World
}

\section{Editors: Matthew McLean and Sara K. Barker}

\section{International Exchange in the Early Modern Book World} presents new research on several aspects of the movement and exchange of books between countries, languages and confessions. It considers elements of the international book trade, the circulation and collection of texts, the practice of translation and the diffusion and exchange of technical and cultural knowledge. Commercial and logistical aspects of the early modern book trade are considered, as are the relationships between local markets and the internationally-minded firms which sought to meet their expectations. The barriers to the movement of books across borders - political, linguistic, confessional, cultural - are explored, as are the means by which these barriers were surmounted.

\section{Readership}

All interested in the international book trade, the circulation and collection of texts, the practice of translation and the diffusion and exchange of technical and cultural knowledge in early modern Europe.

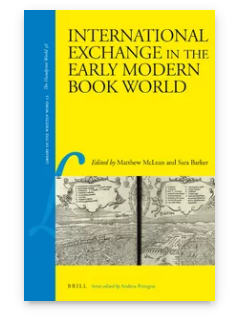

Pages: $x x i i, 383$ pp. With 41 illustrations.

Language:

English

Subjects: Early Modern History, History,

Criticism \&

Theory,

Literature and Cultural Studies, History of the

Book, Book

History and Cartography, General: Book

History \&

Cartography, Book History and Cartography

Publisher: Brill

Series:

Library of the Written Word, Volume: 51 Library of the Written Word The Handpress World, Volume: $5^{1}$

E-Book (PDF) Released online: $11 \mathrm{Jul} 2016$ 
ISBN: 978-90-

o4-31663-8

List price

USD $\$ 208.00$

Hardback

Publication date:

22 Jun 2016

ISBN: $978-90-$

04-31644-7

List price

USD \$208.00

Order information: Order online at brill.com

+44330 333 o049 | customerservices@brill.com

Submission information: brill.com/authors

Titles published by Brill | Fink, Brill | mentis or Brill | Schöningh:

+49(o)71 5413279216 | brill@brocom.de 